\title{
BOTANIC GARDEN PROFILE: KUMPULA BOTANIC GARDEN, HELSINKI, FINLAND
}

\author{
Leif Schulman ${ }^{1} \&$ Maria Hällfors ${ }^{2}$
}

\begin{abstract}
Kumpula Botanic Garden was founded in 1987 on the grounds of an old manor estate. The garden is not particularly big but it was designed and subsequently realised with ambitious scientific and educational goals. It is divided into two main parts: the geobotanical garden and the garden of cultivated plants. The plants in the geobotanical garden are grouped according to their origin and are acquired according to rigorous criteria: only wild-collected plants are accepted and the source areas have been chosen on the basis of the Bioclimatic Zone System that Finnish researchers have been developing since the 1930s. The collection is thus exceptionally valuable for research and conservation. It has already been used for statistical tests on the validity of the bioclimatic vegetation scheme on which it is based. The road from an ambitious vision to a plant collection that is of a scientifically high standard yet also aesthetically pleasing has been long and winding. Here the history and design of the garden and the build-up of the plant collection is described, concluding with a brief account of the inauguration for the general public in June 2009.
\end{abstract}

\section{INTRODUCTION: BIG IS NOT ALWAYS THE MOST BEAUTIFUL}

Kumpula Botanic Garden - the Kumpula plant collections of the Finnish Museum of Natural History - cannot boast about itself in terms of its size or of numbers of plants. Rather, it is a smallish garden, just over six hectares, and the number of plant taxa is fairly modest at 1,500 , represented by a total of around 2,000 accessions. However, the garden was designed and subsequently realised with ambitious scientific and educational goals that, to our knowledge, make it unique among the approximately 2,500 botanic gardens in the world. The story of Kumpula Botanic Garden should therefore be of interest to anyone involved in botanic garden design and development or in the curation of scientific collections of living plants.

Kumpula Botanic Garden was planned in the early 1980s. At that time the traditional systematic arrangement of plantations in botanic gardens had largely given way to the idea of grouping plants by the geographical origin of the species. This was selected as the arrangement in the major part of Kumpula too but the principle was taken even further. Not only were species placed in their respective phytogeographical sections, but even the exact geographical origins of the accessions were used as a decisive factor. Hence, a plant could be placed only in the section corresponding with the area where

1. Leif Schulman is Director of the Finnish Museum of Natural History. Address: PO Box 17 (Pohjoinen Rautatiekatu 13), FI-00014 University of Helsinki, Finland. Email: leif.schulman@ helsinki.fi

2. Maria Hällfors MSc is a doctoral student in the Botany unit, Finnish Museum of Natural History, PO Box 44 (Jyrängöntie

2), FI-00014 University of Helsinki, Finland. Email: maria.hallfors@ helsinki.fi 
the accession was collected, even if the same species would occur naturally in other geographical areas as well. In addition, and more importantly, in the geographical sections of Kumpula only plant material collected in the wild within the natural range of the taxon was accepted. Most of the accessions have thus been collected as seeds, cuttings or seedlings in the field, although some originate from vegetative propagation of wild-collected but garden-grown mother plants.

Because of the strict requirements regarding the quality of the accessions it has not been easy to obtain plants for Kumpula, which together with the northern location explains the garden's rather depauperate flora. On the other hand, every plant grown in the phytogeographical sections of Kumpula can be used for any kind of scientific study that requires genetically pure wild plant material of known origin. In addition, the plants are potentially valuable for conservation at species or population level because of the wild origin and high-quality data on their origin. In the phytogeographical sections there are no redundant accessions that would serve only ornamental purposes. In this sense Kumpula honours the principle that quality can compensate for quantity.

\section{BACKDROP: LOCATION AND ENVIRONMENT}

Kumpula Botanic Garden is situated within the City of Helsinki, approximately $3 \mathrm{~km}$ north of the centre at $60^{\circ} 12^{\prime} \mathrm{N} 24^{\circ} 57^{\prime} \mathrm{E}$. Its area is the core of what was once the second largest manor estate in the region of Helsinki.

Because of its moderately oceanic character and the warming effect of the Gulf Stream, the climate of Helsinki is not quite as harsh as the far northern location would suggest. Summers are cool although maximum temperatures regularly exceed $25^{\circ} \mathrm{C}$ and can reach $30^{\circ} \mathrm{C}$. Winters are relatively mild, but very low temperatures, reaching below $-30^{\circ} \mathrm{C}$, may occur (Finnish Meteorological Institute, 2011). Permanent snow cover lasts on average around 100 days, from late December to late March, and the mean depth of the snow cover during the coldest month of the year (February) is $23 \mathrm{~cm}$ (Finnish Meteorological Institute, 2011). There is typically great year-to-year variation in the onset of seasons so that severe frosts may occur as early as October and as late as April, but on the other hand temperatures above $0^{\circ} \mathrm{C}$ may prevail throughout December and even January. Snow cover may be as thick as $60 \mathrm{~cm}$, while lately some winters have been almost void of permanent snow.

The Kumpula plantations are situated on a gradual south-southwest-facing slope. The garden grounds rise from a bed of clay, which used to be seafloor, and in the lowest parts the groundwater is near the surface. The mid-parts of the slope are of moraine. There are also a few granitic rock outcrops, and the topmost parts of the garden grounds have small areas of about $100 \mathrm{~m}$ in length with a northern inclination. The altitudinal range is roughly $5-15 \mathrm{~m}$ above sea level. In parts of the planting sections the soil has been improved by various means. Hence there is considerable variation in the soil conditions of the plantings. 


\section{SET-UP: DESIGN AND LAYOUT}

Kumpula Botanic Garden was designed by landscape architect Gretel Hemgård. She made use of the old manor setting while also creating a totally new garden in the previously undeveloped or overgrown parts of the area. The garden comprises two main parts (see Fig. 1): the Hortus Geobotanicus (the geobotanical or phytogeographical garden) and the Hortus Ethnobotanicus (the garden of cultivated plants).

The design of the Hortus Geobotanicus largely resembles an English landscape garden, although the scale is modest. The gravel pathways meander between irregularly and softly shaped planting areas that are interspersed with smaller and larger lawns and a few rock outcrops (see Fig. 2). The plants have been grouped according to their areas of origin into separate sections for Europe, eastern North America, western North America, the continental Far East and Japan (see Fig. 1). All these sections stretch from a pond (see Fig. 3) towards higher ground so that different growing conditions, such as shores, humid flats, sunny slopes and dry rock areas, are present in every section. A brook separates the Japanese section from the continental Far East (see Fig. 2) and runs to the pond from which the water drains to a channel that leads down to the sea a couple of kilometres south-east of the garden. In the section for Europe, a separate part

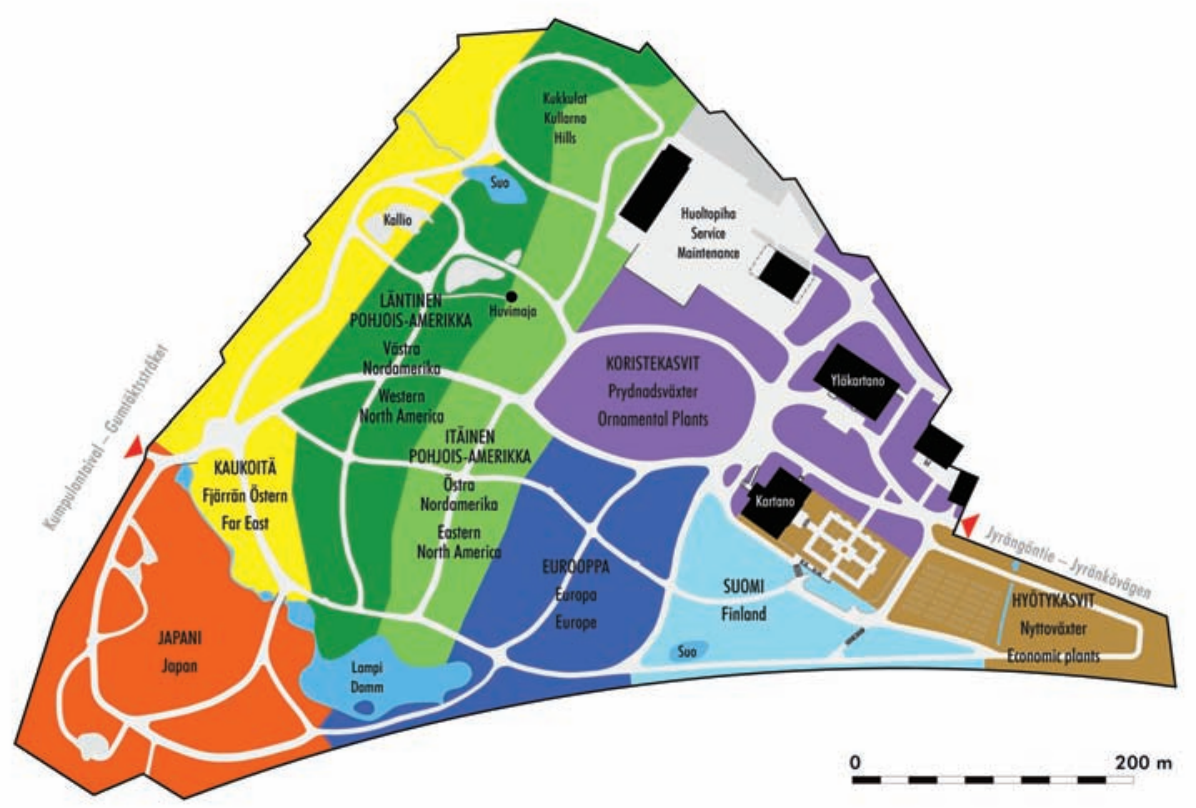

Fig. 1 Kumpula Botanic Garden with section names in Finnish, Swedish and English. The colours on the map depict the sections of the garden. The purple and brown areas make up the Hortus Ethnobotanicus (the garden of cultivated plants) and the others comprise the Hortus Geobotanicus (the geobotanical or phytogeographical garden). Image: courtesy of Finnish Museum of Natural History. 


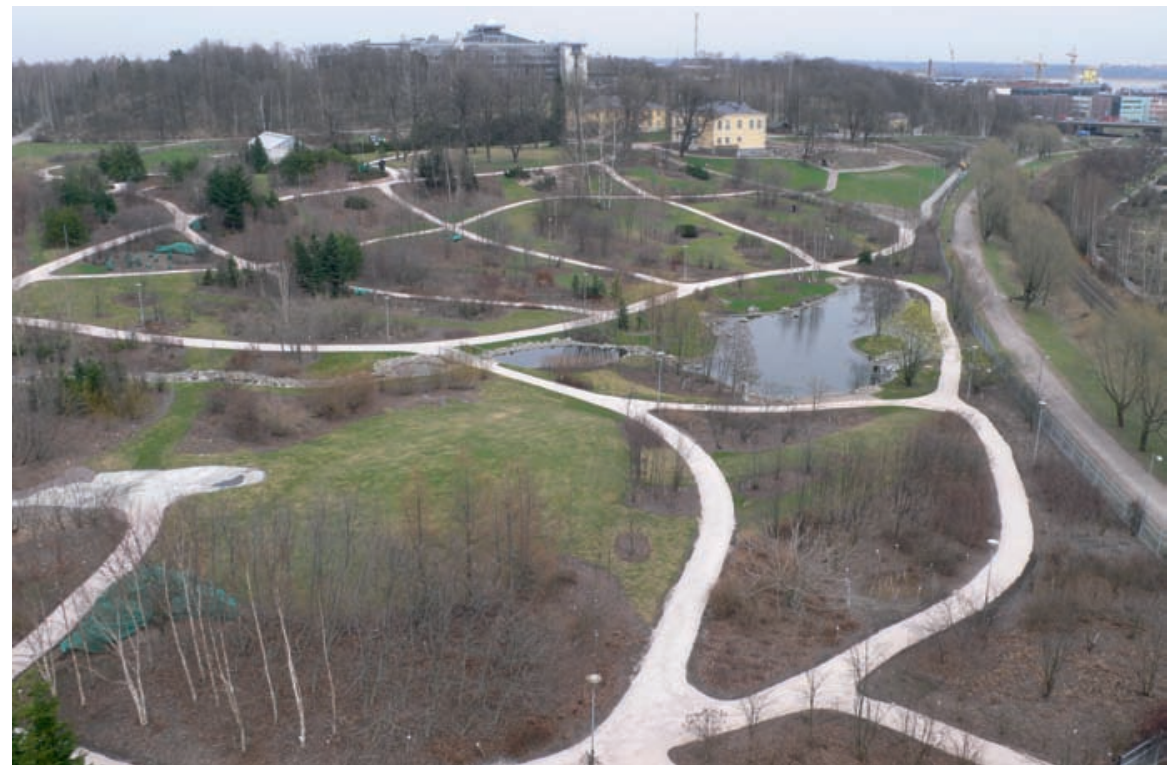

Fig. 2 The Hortus Geobotanicus of Kumpula Botanic Garden seen from the western end of the garden in early spring 2009 with the newly spread, still white, dusty gravel emphasising the path network. The new buildings of the campus housing the Faculty of Science of the University of Helsinki are visible in the background and the Baltic Sea in the upper right corner. The brook that can be seen runs through the garden to the pond and separates the section for Japan from that of the continental Far East. Photo: Marko Pesu.

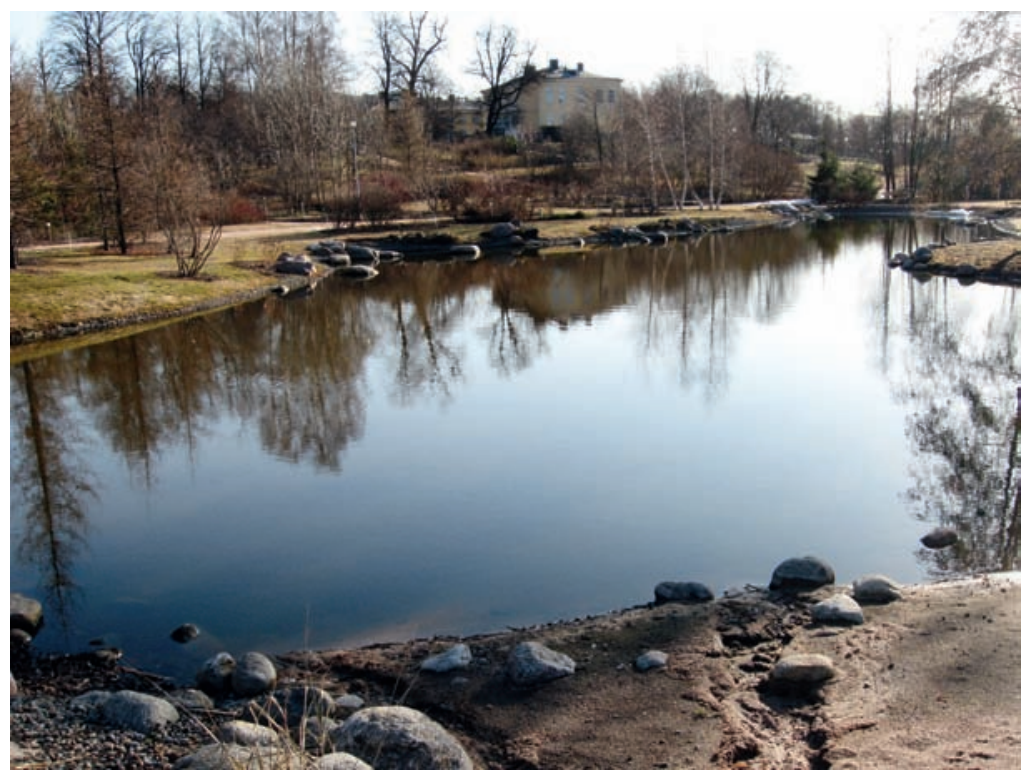

Fig. 3 All geographical sections border the large pond. The shore in the foreground is in the section for Japan, to the left is western North America, then eastern North America and at the back the section for Europe, behind which the manor buildings are visible. Photo: Paula Havas-Matilainen. 
for Finland (Hortus Fennicus) is included (see Fig. 4), where planting started in 2010. In the northern part of the garden, small hillocks have been constructed, on which plants from mountainous areas of Asia and North America will be planted.

The Hortus Ethnobotanicus includes both economic and ornamental species. It is further divided into sections for edible, medicinal and ornamental plants. Amongst the edible ones there are separate sections for fruit and berry plants, and other edible plants. The ornamentals grow in the immediate surroundings of the old manor buildings. In the Hortus Ethnobotanicus geometrical plantings are favoured. Most of the beds are rectangular and many are bordered by flagstones or planks (see Fig. 5). These features emphasise human intervention in these plants, most of which are cultivars.

\section{THE PLANT COLLECTION: SCIENTIFIC RIGOUR}

\section{AND METICULOUS RECORDING}

In addition to the acceptance of only wild-collected material to the geographical sections, the truly unique feature of Kumpula Botanic Garden is that its whole Hortus Geobotanicus actually forms a test of the validity of a large-scale vegetation map.

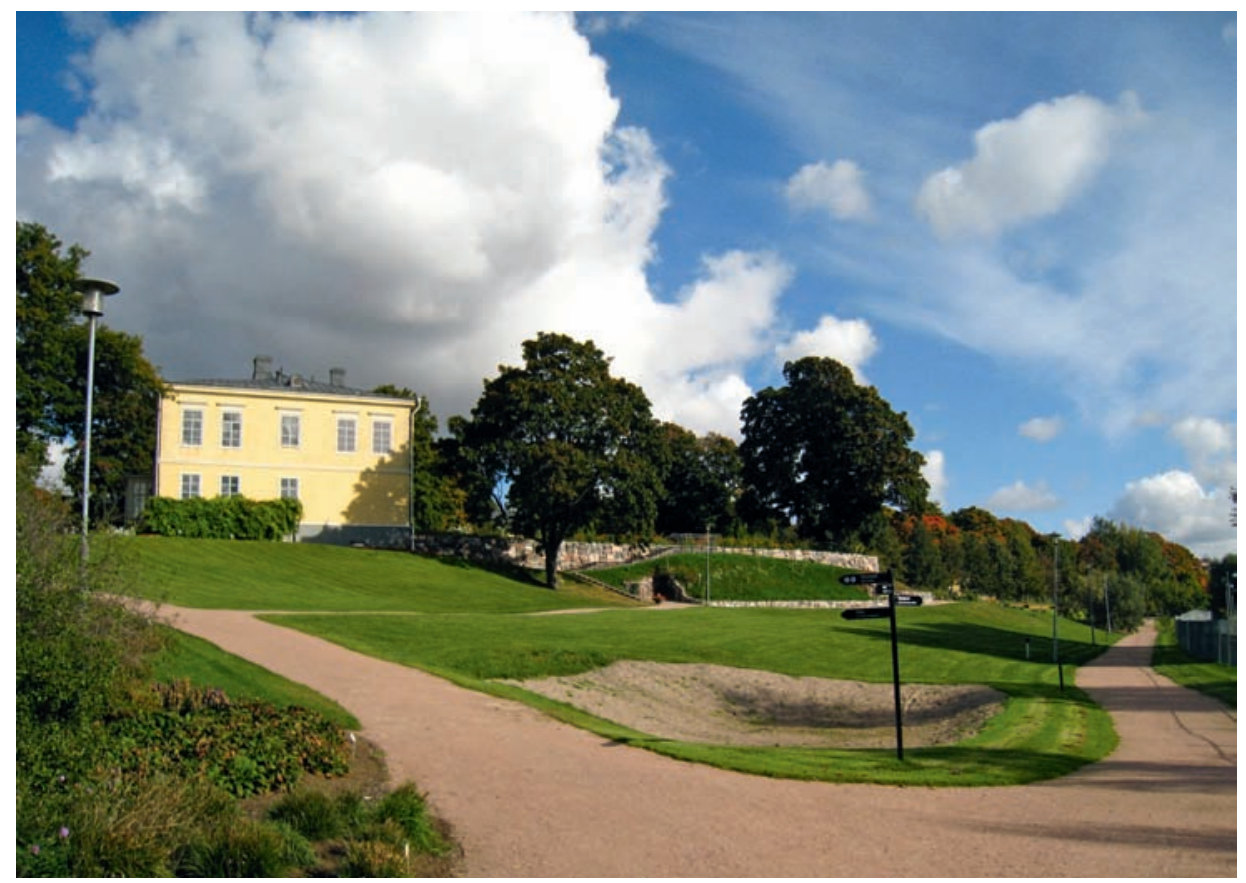

Fig. 4 An annex to the section for European plants was cleared from previous plantings during the renovation project in 2006-2009 and is now reserved for the native flora of Finland, which has been gathered here since 2010. The pit in the foreground will be filled with peat and developed into a suitable site for mire plants. In the background is the main manor building. Photo: Maria Hällfors. 


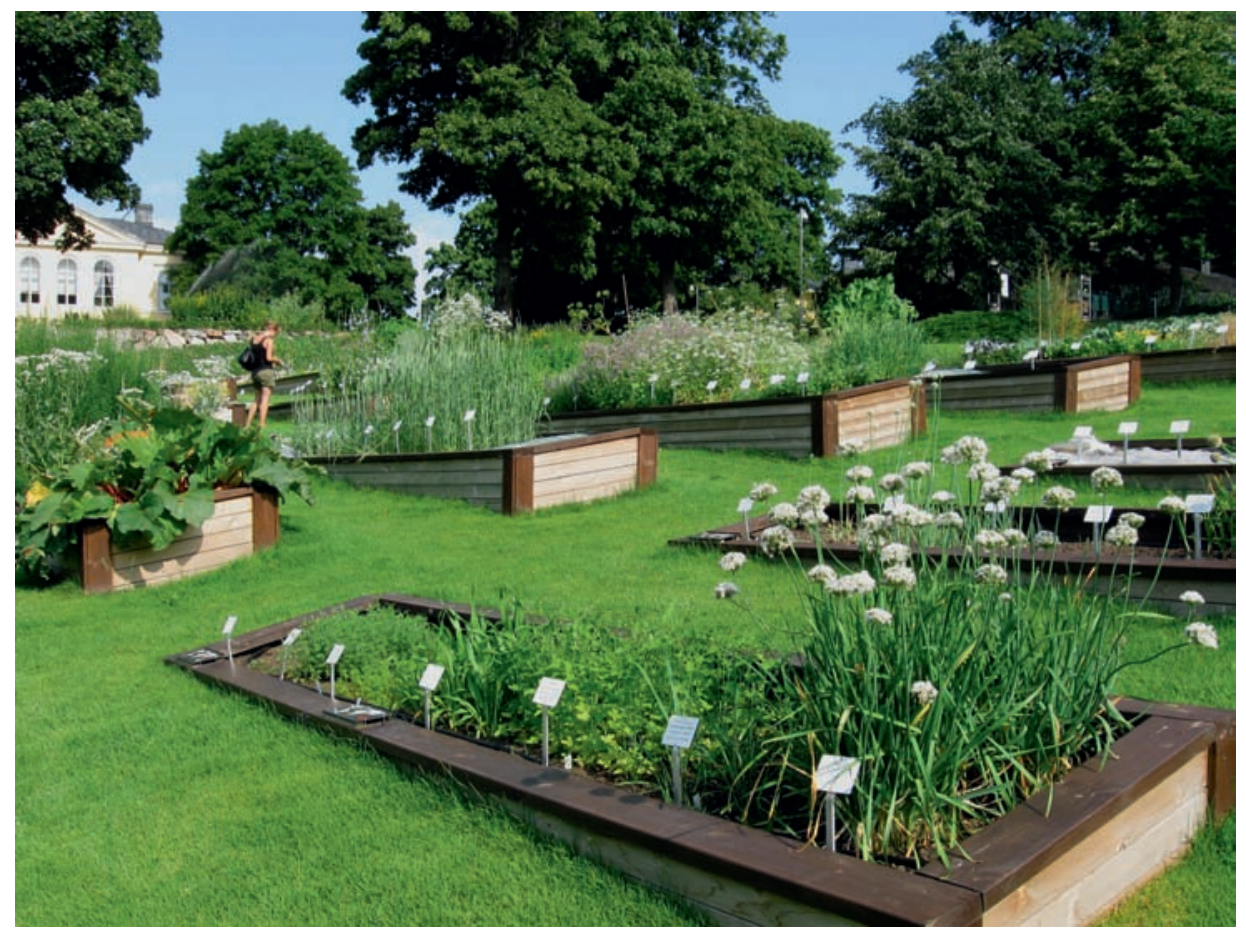

Fig. 5 The section for edible plants in mid-July 2010. The beds are bordered by plank frames, which are fitted to the inclined terrain to create horizontal planting surfaces. The plants are arranged according to their areas of domestication, maps of which are fitted on the lower part of the frame. Photo: Paula HavasMatilainen.

The Finnish school of bioclimatic vegetation mapping, which started with the studies of Aarno Kalela in the 1930s, gradually produced a map of vegetation zones for the northern parts of the northern hemisphere (Kalela, 1961; Ahti et al., 1968; Hämet-Ahti et al., 1974; Ahti, 1980; Tuhkanen, 1980, 1984; Hämet-Ahti, 1981) and was established as the so-called Bioclimatic Zone System (BZS; Goward \& Ahti, 1992). The word 'bioclimatic' refers to the notion that the prevailing climate is the foremost factor shaping the vegetation formations and the flora and fauna of a given area. The BZS divides the boreal zone and its adjacent zones (the temperate zone to the south and the arctic zone to the north) into regions that are supposedly climatically and, therefore, phytogeographically corresponding. The delimitation of the regions roughly follows the latitudes (see Fig. 6a) although this pattern is interrupted by variation in edaphic and altitudinal features, and is complemented by the variation in the degree of continentality and oceanity as the zones traverse the continental land masses. For any given zone, bioclimatically similar belts can be found in mountain areas south of the main distribution area of that zone. According to the BZS the mountain zones are bioclimatically more or less equivalent to the corresponding zones at sea level (Ahti et al., 1968). 
Following the BZS, Kumpula Botanic Garden lies at the northern limit of the hemiboreal zone, very close to the southern boreal zone (Ahti et al., 1968; see Fig. 6b). With the establishment of the new botanic garden, an opportunity opened to test the hypothesis that plants that have been moved between corresponding bioclimatic areas should thrive, whereas plants moved from colder (more northern) or warmer (more southern) zones are less likely to grow well. For this reason Kumpula Botanic Garden organised seed-collecting expeditions to target areas that are homoclimatic with southern Finland (see Fig. 7). Five expeditions were carried out: to Hokkaido, Japan, in 1993 (see Fig. 8); to north-east China in 1994; to British Columbia and Alberta, Canada, in 1995; to the mountains of Honshu, Japan, in 1999; and to mountainous areas of Bulgaria in 1999. For descriptions of the first three expeditions and locations visited see Koponen and Koponen (1994, 1995, 1996).

On the expeditions, data on the origin of each collection was recorded carefully and the collectors noted the bioclimatic zone of the site. From the expeditions a total of 1,108 accessions were brought back, of which 781 germinated and survived through propagation to be planted in the outdoor sections of the garden (see Table 1). Many of the accessions were represented by several tens and even up to around one hundred plants. The number of surviving individuals was subsequently recorded and updated on

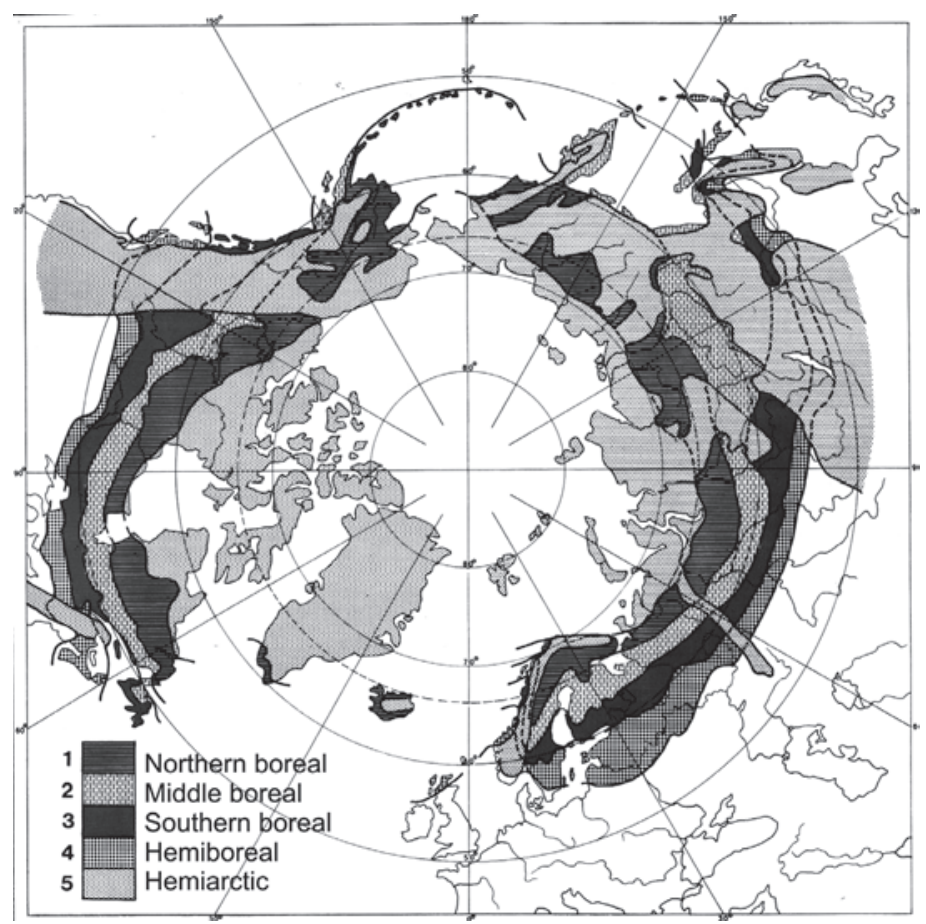

Fig. 6a The circumboreal zone and its transcontinental subzones according to Hämet-Ahti (1981). Reproduced with kind permission from the Finnish Geographical Society. 


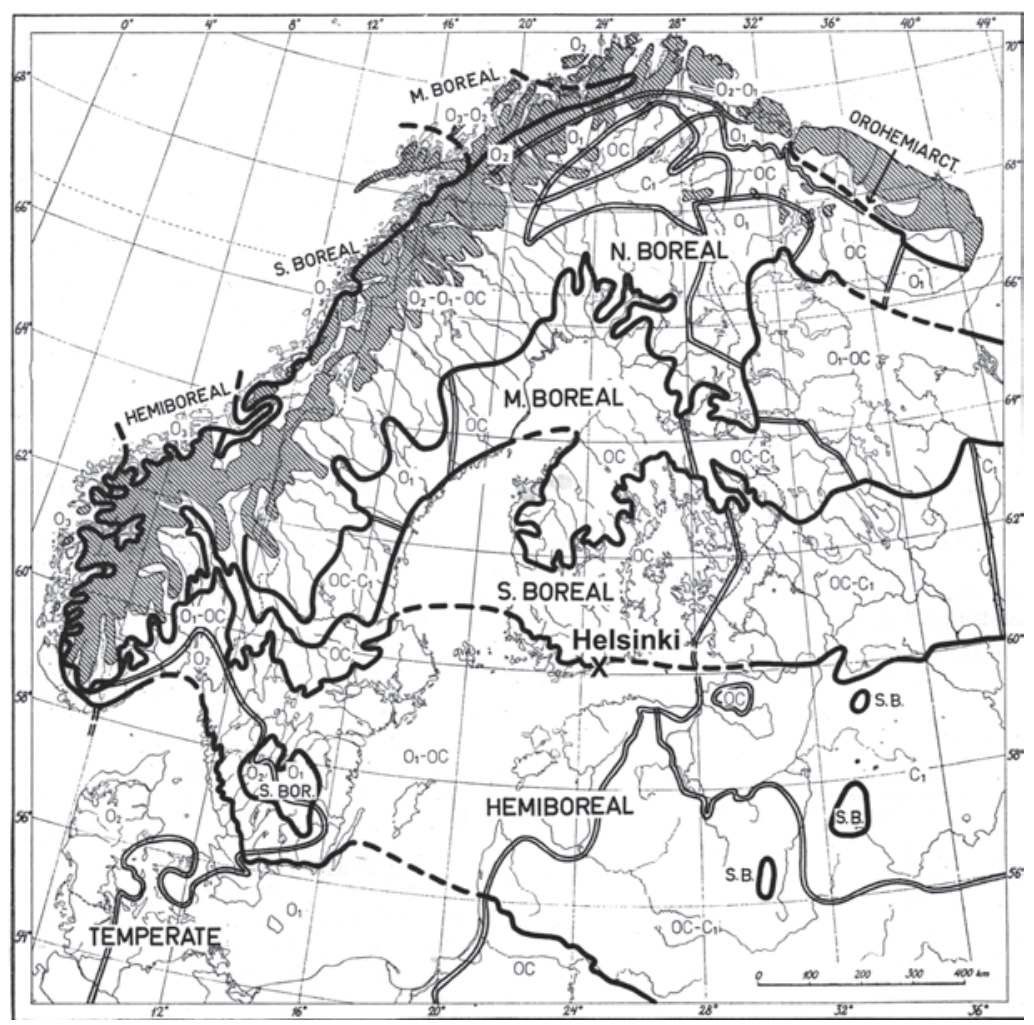

Fig. 6b The vegetation zones and their sections in north-western Europe according to Ahti et al. (1968). The position of Helsinki has been added. Reproduced with kind permission of the authors.

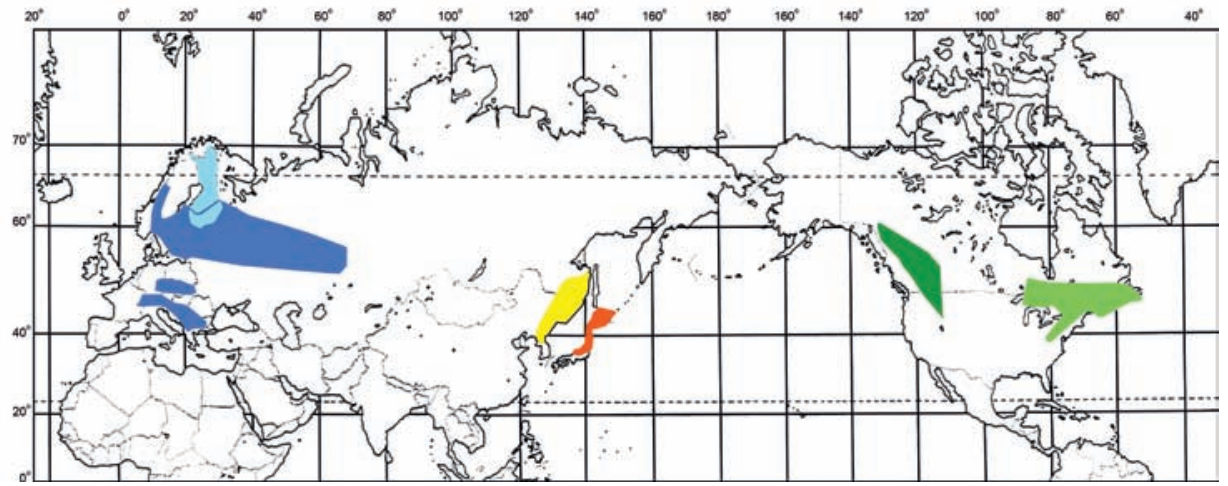

Fig. 7 Areas that correspond to southern Finland climatically, that is those that are defined as homoclimatic areas for the purpose of collecting plant material for Kumpula Botanic Garden (Koponen \& Koponen, 2002). The colours on the map correspond with the colours used to denote the geobotanical sections of Kumpula Botanic Garden shown in Fig. 1. Photo: Courtesy of Finnish Museum of Natural History. 
a regular basis in the database. The combination of carefully collected data and regular inventories later enabled a statistical analysis on whether the survival probability of the plants depended on the bioclimatic source zone. The analysis lent support to the hypothesis (Hällfors et al., 2011), even if the results were somewhat blurred by various curatorial problems during the development of the plantings (Hällfors et al., 2010).

\begin{tabular}{|l|c|c|c|c|c|c|}
\hline & Japan -93 & China & Canada & Japan -99 & Bulgaria & Total \\
\hline Total collected & 402 & 336 & 250 & 55 & 69 & $\mathbf{1 , 1 1 2}$ \\
\hline Planted in garden & 221 & 278 & 215 & 39 & 28 & $\mathbf{7 8 1}$ \\
\hline
\end{tabular}

Table 1 Numbers of accessions collected during the expeditions on which material for Kumpula Botanic Garden was gathered and numbers of accessions from these expeditions planted in the outdoor sections of the garden.

In addition to the expeditions mentioned above, plants for Kumpula Botanic Garden have also been obtained through international seed exchange between botanic gardens whenever wild-collected material has been available from climatically suitable areas. Of the current total of around 1,500 accessions in the Hortus Geobotanicus, representing approximately 1,000 different taxa (see Fig. 9), a little over half originate from seed exchange and the rest from the Garden's own expeditions.

The Hortus Ethnobotanicus partly reiterates the geographical theme of the Hortus Geobotanicus: the edible herbaceous plants are arranged according to the area of domestication, that is where the plant was originally taken into cultivation (see Fig. 10). The medicinal plant collection, however, is arranged according to the traditional medical use of the plants. There are thus separate sections for plants that, among other things, improve immune response and general health, reduce respiratory problems, alleviate pain, cure women's diseases or affect moods. The collection of ornamental plants focuses on cultivars that were commonly planted in manor gardens when the current manor buildings were built, in the mid-1800s. At this time Finland was part of the Russian Empire. Hence many of the presented cultivars of groups such as

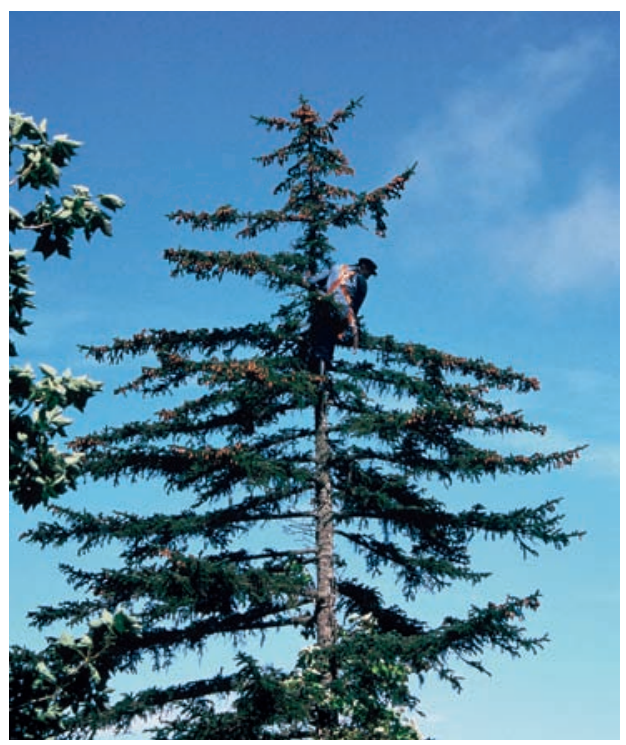

Fig. 8 Garden technician Martti Koponen collecting seeds of Sakhalin spruce (Picea glehnii) for Kumpula Botanic Garden in Japan in 1993. The collection was successful: 24 trees now grow in section 267 in the garden. Photo: Courtesy of Finnish Museum of Natural History. 

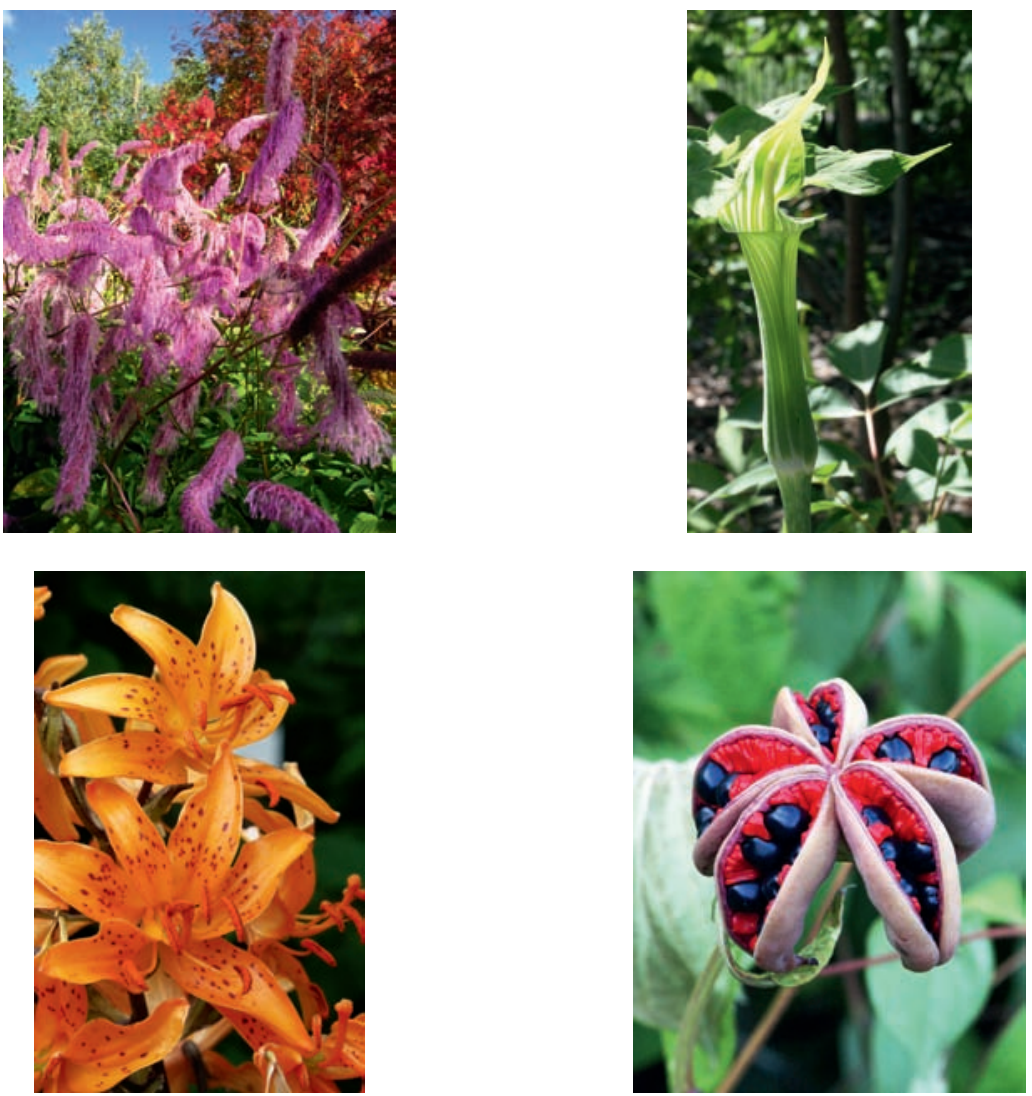

Fig. 9 Many of the wild-collected perennials in Kumpula Botanic Garden are vigorous and provide a vivid display of form and colour: (a) Sanguisorba japonensis; (b) Arisaema serratum; (c) Lilium distichum; (d) Paeonia obovata. Photos: (a) Maria Hällfors, others Visa Lipponen.

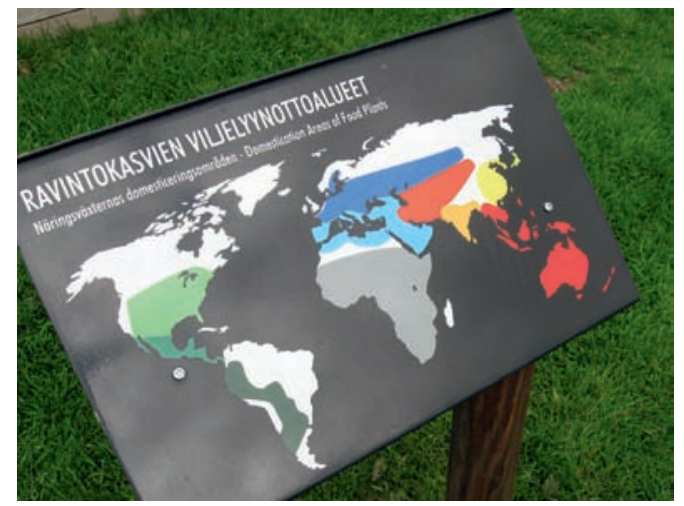

Fig. 10 The domestication areas of crop plants as shown on a board in the Hortus Ethnobotanicus of Kumpula Botanic Garden. In the section for edible plants the taxa are planted in an arrangement reflecting the map (compare with Fig. 4). Photo: Courtesy of Finnish Museum of Natural History. 
roses and poplars are of eastern origin and are thus not common in western European gardens. The total collection of the Hortus Ethnobotanicus comprises approximately 500 accessions, representing some 400 species or cultivars.

\section{HISTORY: FROM ANCIENT MANOR TO MODERN GARDEN}

In the year 1498, when Finland was part of the Kingdom of Sweden, the farm that included the present garden grounds, then known by the Swedish name Gumtäkt or Gumteckt, received tax exemption from the king and became a manor estate. The manor never stayed in the same family for very long, but went through numerous changes of ownership over the centuries. The current buildings (see Fig. 11) date from the 1840s, when the manor enjoyed its heyday under the ownership of Baron Johan Gabriel von Bonsdorff. However, by 1893 the estate had been sold to the City of Helsinki. The National Board of Health rented the manor as an "additional venereal hospital" from 1905 to 1960 during which period the Finnish name Kumpula came into use. The manor functioned as an elementary school between 1962 and 1977 before becoming state property and part of the real estate governed by the University of Helsinki.

As a result of the fragmented history of the estate, no real manor park was ever developed in Kumpula; only a small area in the immediate vicinity of the manor

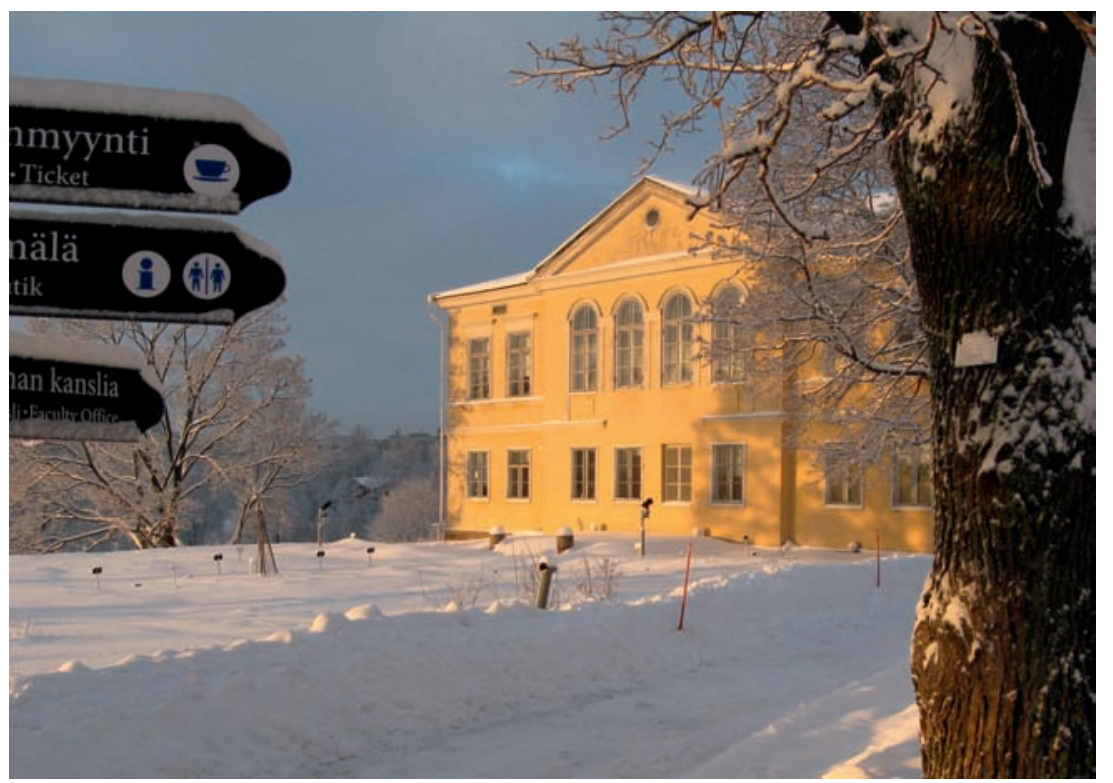

Fig. 11 The main building of Kumpula Manor in December 2010. The building dates from the 1840s, as do two other buildings in Kumpula Botanic Garden. In front of the Manor, which houses the administrative office of the Faculty of Science of the University of Helsinki, is the section for medicinal plants, which is arranged according to the traditional medicinal use of the species. Photo: Paula Havas-Matilainen. 
buildings had been planted with trees such as oak, lime and maple. However, the botanical heritage value of Kumpula is enhanced by the extraordinary coincidence that Peter Forsskål (1732-1763), one of the disciples of Carl Linnaeus, grew up here when his father Johannes owned the estate in 1733-1739. The childhood home of one of Finland's most significant botanists was thus converted into a botanic garden almost exactly 250 years after his birth.

The formal year of establishment of Kumpula Botanic Garden was 1987, when the fence around the garden was completed. The first plantings were made at around the same time, but the introduction of new plants peaked in the latter half of the 1990s as a consequence of the above-mentioned expeditions. In the most active years, tens of thousands of seedlings were produced in the garden's own nursery and subsequently planted out in the collections.

The founding phase of Kumpula Botanic Garden was a major strain on the resources of the institution since the collection in the city centre, the historical Kaisaniemi Botanic Garden, had to be maintained at the same time and staff numbers were not increased despite the Kumpula project. One of the solutions to the staff shortage was an attempt to reduce the need for weeding and irrigation in the newly established plantings. To this end, Mypex ${ }^{\circledR}$, a woven plastic sheet, was used to cover the soil in all the planted sections. Mypex ${ }^{\circledR}$ prevents weed germination and the growth of weed roots underneath it. It allows the penetration of rainwater while slowing down the loss of water through evaporation. Plantlets were planted in holes cut into the Mypex ${ }^{\circledR}$ sheet, and the sheet was subsequently covered with mulch of milled bark.

During its first two decades, Kumpula Botanic Garden was used for research and teaching mainly by university staff and students. It was not open to the public apart from sporadic guided tours arranged by appointment. However, the inauguration of the garden for the public had been scheduled for 2010 at the time of its establishment. Preparations for the opening were started in 2005. On 10 June 2009, one year ahead of schedule, the public were shown what was hidden in 'the secret garden'.

\section{OPENING PROJECT: INAUGURATION FOR PRESENT AND FUTURE GENERATIONS}

After the active founding stage, Kumpula Botanic Garden fell into a state of stagnation. Resources were scarce and because the garden was closed to the public, the maintenance of the infrastructure, such as pathways, and aesthetically high-level gardening could not be prioritised. As a result, the overall condition of the garden deteriorated from the latter half of the 1990s to the year 2005 (see Fig. 12). Furthermore, the ample use of Mypex ${ }^{\circledR}$ started to take its toll. It turned out that Mypex ${ }^{\circledR}$ was harmful for most of the plantings. The natural vegetative spreading of shrubs and perennials was hindered, normal decomposition and soil-forming processes were disturbed, the roots of plants developed abnormally because of altered moisture conditions, the slits cut for the originally tiny plantlets started strangling thickening tree trunks and the weed problem was actually 


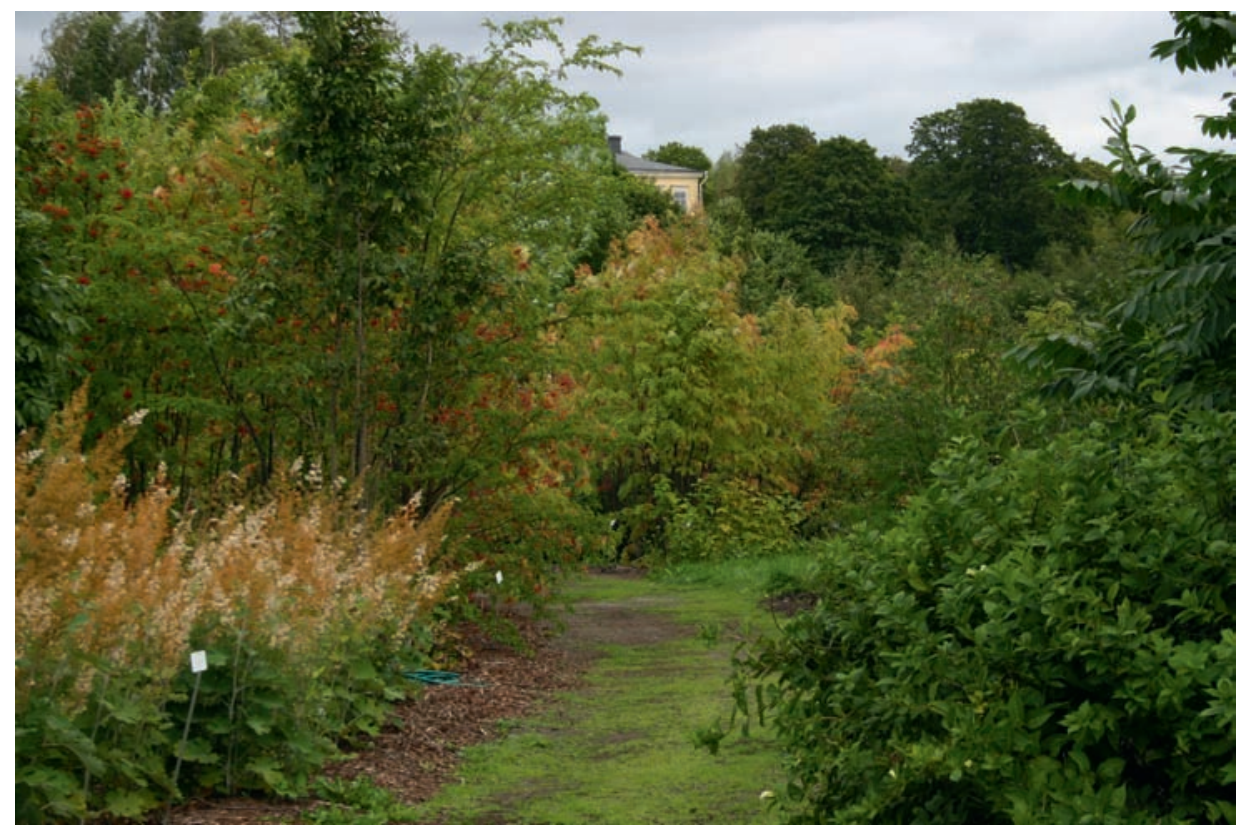

Fig. 12 Kumpula Botanic Garden deteriorated after the active founding stage in the late 1980s to early 1990s. Many plantings became overgrown and vistas were lost. The renovation work that culminated in the inauguration in June 2009 was started in 2006. Photo: Mikko Heikkinen.
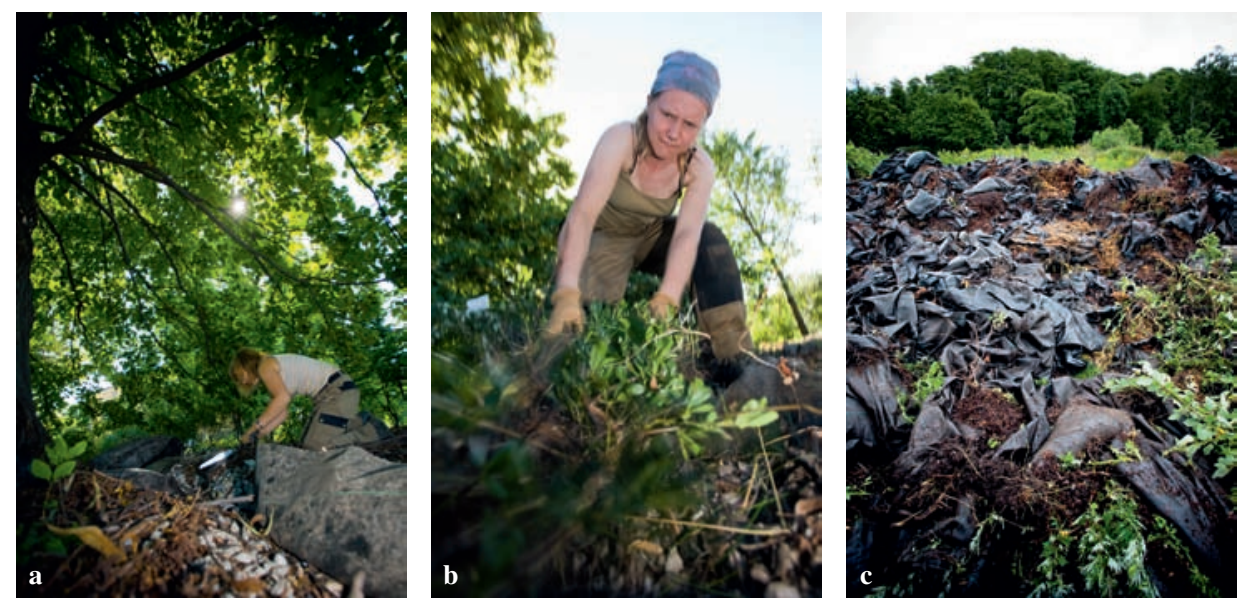

Fig. 13 The removal of Mypex ${ }^{\circledR}$ in 2007. Removal of this was necessary because it had started harming the plants during the almost 20 years it had been in place. The sheets were cut into pieces (a) for easier removal, but even so the material was very hard to pull off the ground (b) since the roots of weeds and collection plants had tightly bound it to the ground. The work resulted in enormous piles of Mypex ${ }^{\circledR}$, weeds and soil (c). Photos: Mikko Paartola. 
accelerated through increased competition in the slits as a consequence of the fact that the collection plants could not form dense, shading stands. Therefore, when the preparations for the inauguration of the garden finally started, the first task was to thoroughly rehabilitate the plantings as well as the infrastructure of the garden.

The bold decision to remove the approximately three hectares of Mypex ${ }^{\circledR}$ was taken and the hard work was carried out in the summers of 2006 and 2007 (see Fig. 13a-c). At the same time damaged saplings were removed and some very densely planted stands of some shrub accessions were thinned. All the perennials - thousands of plants - were lifted, moved to the nursery and replanted into the collections after soil improvement of the beds. Some of the landscape features of the original garden design that had been ignored and therefore lost during the intense planting phase were restored by discarding some plants and moving others. Some other rearrangements of the collections, mainly in Hortus Ethnobotanicus, were also realised. All the pathways were renovated and much of the power cable networks were relaid. A major undertaking was the dredging and rebuilding of the pond that had silted up and become overgrown (see Fig. 14a and

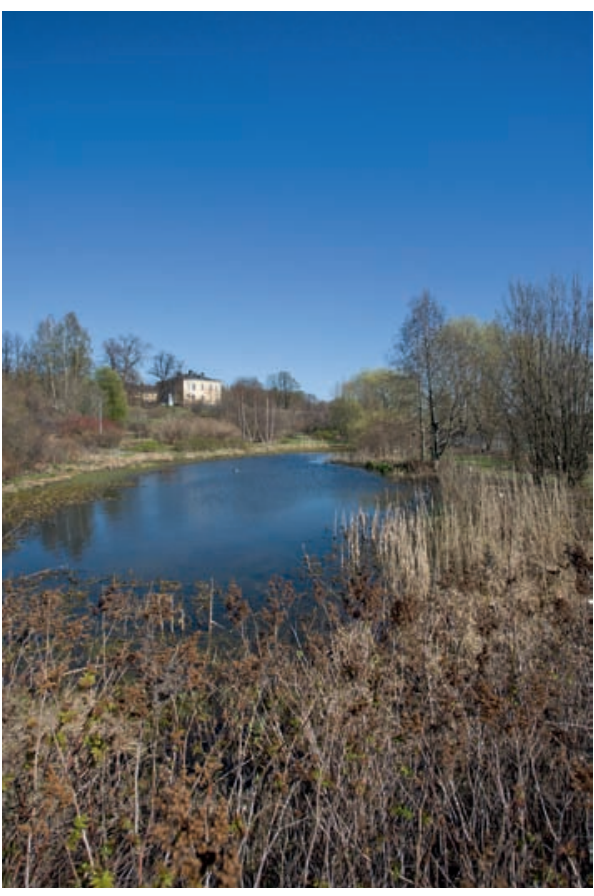

Fig. 14a The pond had become overgrown and silted up after years of insufficient maintenance; the photograph shows the condition in April 2007. Photo: Mikko Paartola.

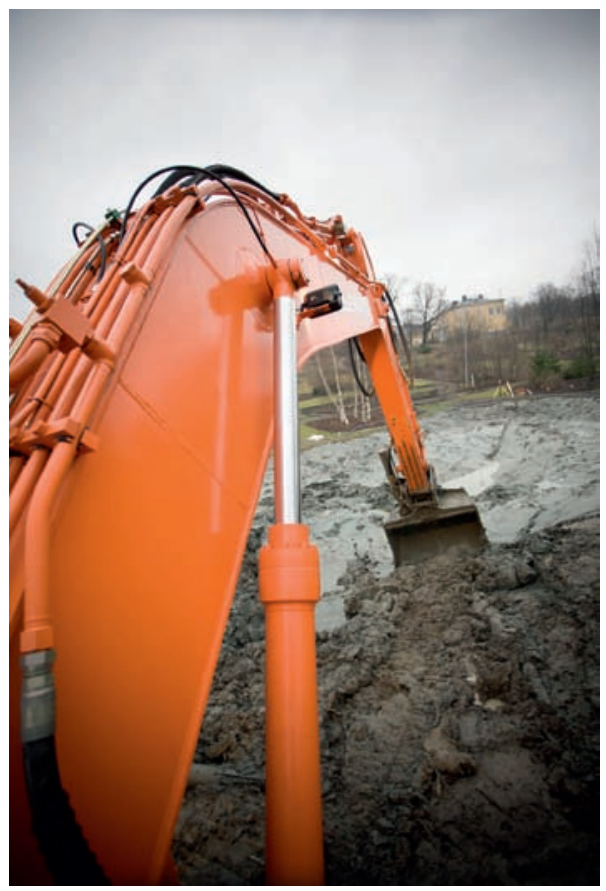

Fig. 14b Dredging the pond in January 2008. The work was scheduled for mid-winter with the expectation that the frozen ground would support the heavy machinery but the winter of 2007-2008 was one of the mildest ever recorded and the soil never froze properly. See Fig. 3 for the rebuilt pond. Photo: Mikko Paartola. 
b). The brook traversing the garden was also rebuilt as was the bridge crossing it. The restoration of the garden was funded by the University of Helsinki.

Alongside the refurbishment of the actual garden, the necessary customer service and educational facilities were planned and built. Traditional information boards were avoided in the garden in order to maintain the natural feel of the garden and not to disturb the views. Instead, numbered poles were installed and explanations provided in the visitors' leaflet. The publication of guidebooks was supported by the Finnish society of biologists, Societas Biologica Fennica Vanamo. A gazebo and benches were produced for the garden by a local organisation that employs the long-term unemployed to produce various products out of recycled materials.

The arrangement of the plants in the collection according to geographical origin, place of domestication or medicinal qualities is intended to give the visitor new insights into plantlife whilst strolling in the garden. The collection is also adaptable to different kinds of educational activities, such as guided tours. This educational aspect has been continued in the shop and café that have been built. It reflects the plant collections by offering products made of plant species that can be found growing in the garden. To emphasise this, the products are introduced in the shop with labels similar to those used in the garden for the actual plants. Many of the delicacies sold in the café are also equipped with tags to indicate which plants have been used in their production.

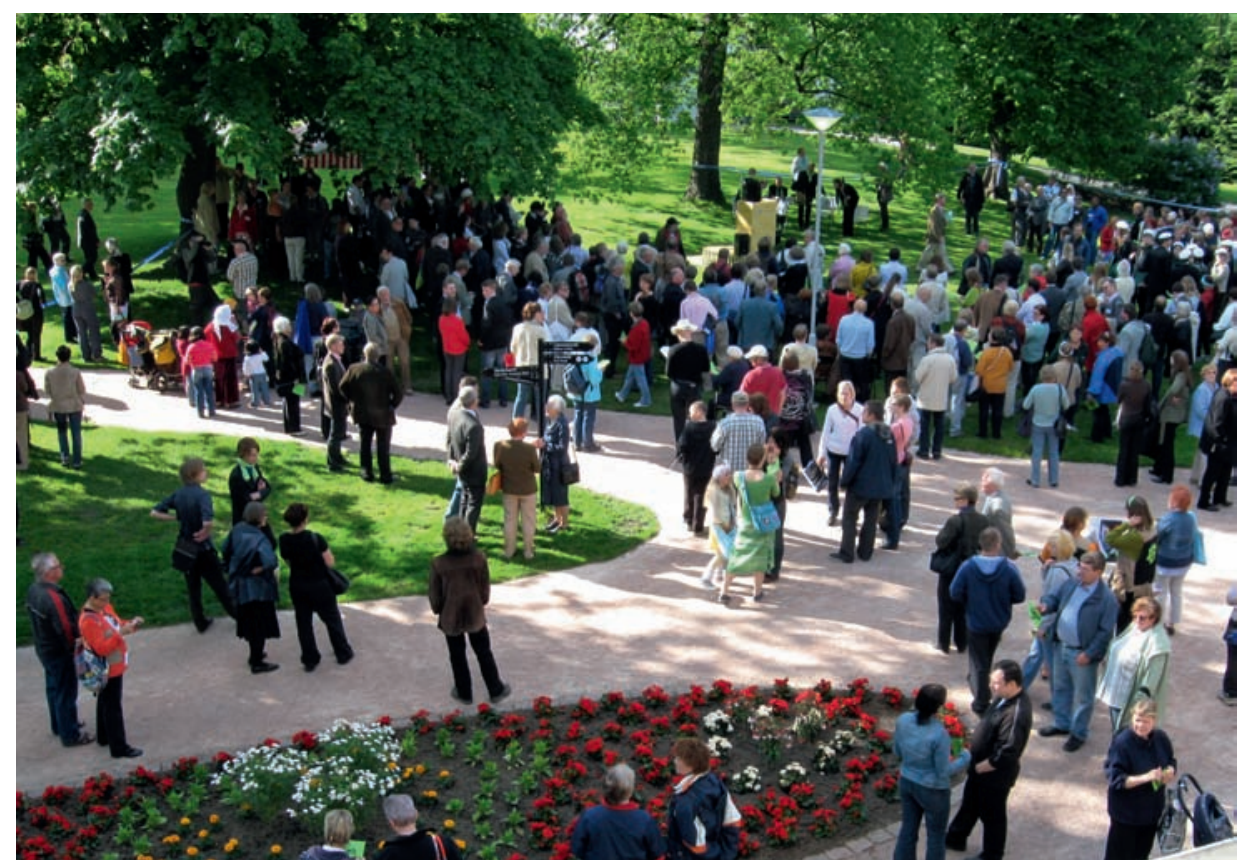

Fig. 15 The inauguration festivities of Kumpula Botanic Garden on the evening of 10 June 2009 attracted more than 1,000 visitors in addition to the 400 invited guests. Photo: Paula Havas-Matilainen. 
Additionally, the shop and café promote a green lifestyle by selling mainly vegetarian and ecological products, Fairtrade tea and coffee, and ecological souvenirs, often showcasing local artisans and producers.

The inauguration festivities of Kumpula Botanic Garden were combined with the hosting of the Fifth European Botanic Gardens Congress (EuroGard V) from 8 to 12 June 2009. The inauguration of the garden was the main social event of the congress during which around 200 international guests alongside around another 200 other invited guests witnessed the official opening on 10 June together with more than 1,000 visitors who arrived for the public opening (see Fig. 15). The Minister of Education together with the Rector of the University of Helsinki opened the garden simultaneously to both the citizens and, symbolically, the international scientific community (see Fig. 16). The Congress was funded by the Ministry of the Environment and several private foundations and both the Congress and the inauguration received minor support from private enterprises.

The garden attracted approximately 25,000 visitors during the first season, which must be regarded as a success considering that the total population of Helsinki is only just over 500,000 and that the garden is closed from the end of September to the end of April. For comparison, Kaisaniemi, which also has tropical greenhouses, is open all year and is situated in the centre of Helsinki, had about 50,000 visitors in the same year.

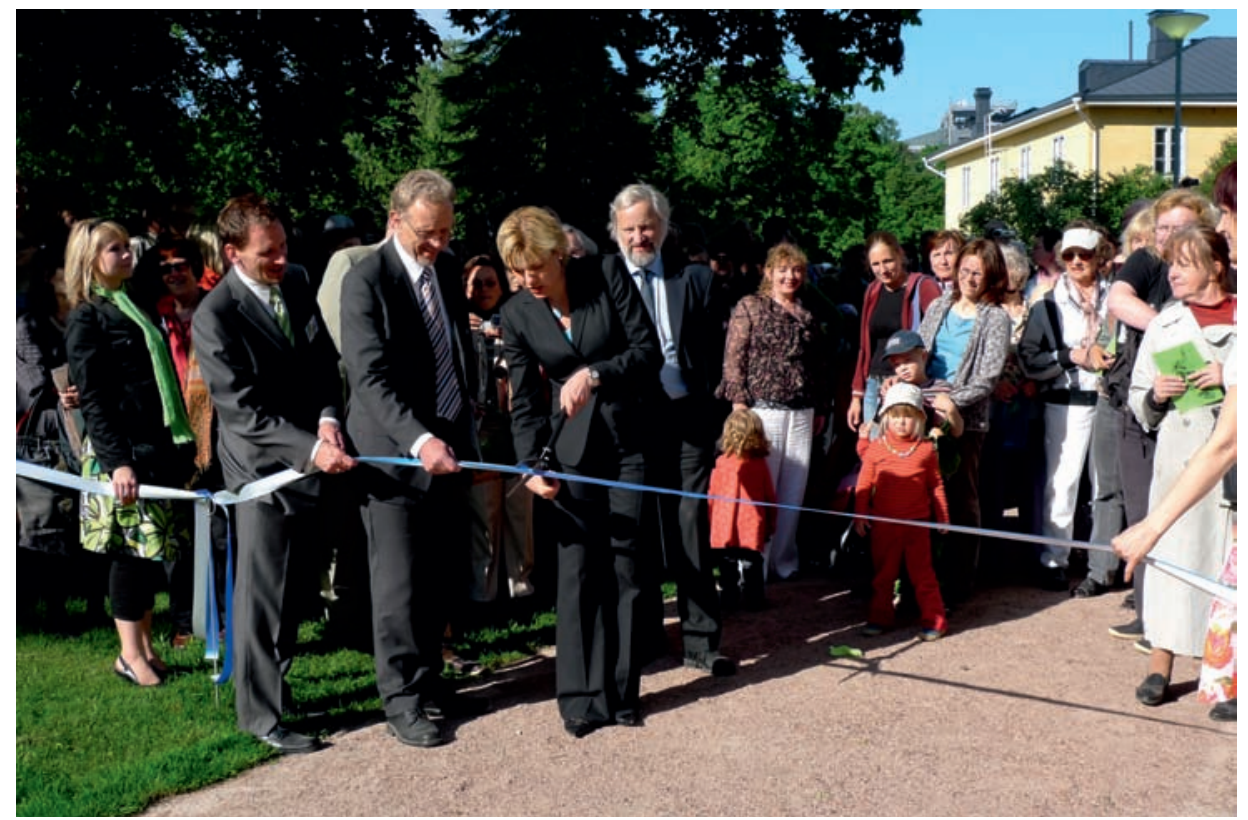

Fig. 16 The Minister of Education, Ms Henna Virkkunen, cut the ribbon with the Rector of the University of Helsinki, Prof. Thomas Wilhelmsson, to symbolise the opening of Kumpula Botanic Garden to the general public. Behind Ms Virkkunen is the Chancellor of the University, Prof. Ilkka Niiniluoto. Photo: Laura Hiisivuori. 
They say a garden is never ready, and this applies to Kumpula Botanic Garden too. On a recent expedition to Kirghizia, more than 150 accessions were gathered for the collection of montane floras to be planted on the hillocks in the northern corner of the garden. Planting in the section for Finnish plants (see Fig. 4) has only just begun and it will take many years before the ambitious goal of a complete coverage of the national flora has been achieved. The educational value of the garden will be increased through the introduction of plant species included in the national curriculum for elementary schools. Further, in the slightly more distant future the applicability of the Bioclimatic Zone System and the identification of homoclimatic areas of Helsinki will have to be revisited. Given the current progress of climate change, Kumpula Botanic Garden may soon have to incorporate temperate floras such as that of Central Europe.

\section{REFERENCES}

AHTI, T. (1980). Definition and subdivision of the subarctic. A circumpolar view. Canadian Botanical Association Bulletin 13(2) (supplement), 3-10.

AHTI, T., HÄMET-AHTI, L. \& JALAS, J. (1968). Vegetation zones and their sections in Northwestern Europe. Annales Botanici Fennici 5, 169-211.

FINNISH METEOROLOGICAL INSTITUTE (2000). Available at: http://en.ilmatieteenlaitos.fi/ normal-period-1971-2000 (accessed 15 June and 20 July 2011).

GOWARD, T. \& AHTI, T. (1992). Macrolichens and their zonal distribution in Wells Gray Provincial Park and its vicinity, British Columbia, Canada. Acta Botanica Fennica 147, 1-60.

HÄLLFORS, M., SCHULMAN, L., LINDÉN, L. \& RITA, H. (2010). Testing bioclimatic hypotheses with botanic garden collections - curatorial considerations. Proceedings of the 4th Global Botanic Gardens Congress - Addressing global change: a new agenda for botanic gardens, 13-18 June 2010, Dublin, Ireland. Available at: www.bgci.org/files/ Dublin2010/papers/Hällfors-Maria.pdf (accessed 8 September 2011).

HÄLLFORS, M.H., LINDÉN, L., RITA, H. \& SCHULMAN, L.E. (2011). Using a botanic garden collection to test a bioclimatic hypothesis. Biodiversity and Conservation 20(2), 259-275.

HÄMET-AHTI, L. (1981). The boreal zone and its biotic subdivision. Fennia 159(1), 69-75.

HÄMET-AHTI, L., AHTI, T. \& KOPONEN, T. (1974). A scheme of vegetation zones for Japan and adjacent regions. Annales Botanici Fennici 11, 59-88.

KALELA, A. (1961). Waldvegetationszonen Finnlands und ihre klimatischen Paralelltypen. Archivum Societatis Zoologicae-Botanicae Fennicae 'Vanamo' 16 (supplement), 65-83.

KOPONEN, T. \& KOPONEN, A. (1994). Delectus seminum. List of seeds available in 1994. Supplement. Seeds from natural habitats in Hokkaido, Japan. Botanical Garden, University of Helsinki.

KOPONEN, T. \& KOPONEN, A. (1995). Delectus seminum. List of seeds available in 1994. Supplement 2. Seeds from natural habitats in Northeast China. Botanical Garden, University of Helsinki. 
KOPONEN, T. \& KOPONEN, A. (1996). Delectus seminum. List of seeds available in 1996. Supplement 3. Seeds from natural habitats in Canada. Botanical Garden, University of Helsinki.

TUHKANEN, S. (1980). Climatic parameters and indices in plant geography. Acta Phytogeographica Suecica 67, 1-100.

TUHKANEN, S. (1984). A circumboreal system of climatic-phytogeographical regions. Acta Botanica Fennica 127, 1-50. 